\title{
Development of Inorganic Molecular Shape Model Using 3D Printer to Strengthen Student's Conceptual Understanding
}

\author{
Rizal Galih Pratama ${ }^{1^{*}}$ and Johnsen Harta ${ }^{1}$ \\ ${ }^{1}$ Chemistry Education Study Program, Faculty of Teachers Training and Education, \\ Sanata Dharma University, Paingan, Maguwoharjo, Depok, Sleman Yogyakarta, 55282, \\ Indonesia \\ *E-mail: rizal.galih17@gmail.com
}

Received: 21 September 2021; Accepted: 21 November 2021; Published: 31 Desember 2021

\begin{abstract}
This research aims to develop a product in the form of an inorganic molecular shape model using a 3D printer, analyze the validity, practicality, effectiveness of the product, and strengthen students' conceptual understanding using the product. The method is Research and Development (R\&D) based on the Analysis, Design, Development, Implementation and Evaluation (ADDIE) model. The supporting instruments for this research are product and instrument validation sheets, product readability questionnaires, pretest-posttest questions, question during the trial, observation sheets for students' conceptual understanding, and student response questionnaire to the product. The results showed that the product developed was following the ADDIE model because the five stages were carried out systematically; the product being developed has very high validity with an average percentage of $96.88 \%$; the average percentage of practicality is $95.17 \%$ which is categorized as very practical, and the average percentage of effectiveness is $94.69 \%$ which is categorized as very effective; the product developed can strengthen students' conceptual understanding shown on the average percentage of conceptual understanding indicators achievement during the trial was $90.61 \%$ and the observation result was $94.69 \%$, both of which belong to very high category. There was an increase in the average pretest value of 33.93 and post-test of 63.99. The results of the Rasch analysis after using this product showed that the consistency of students' answers was 0.71 (quite good), the quality of the items was 0.93 (very good), and the interaction between the consistency of students' answers was 0.68 (quite good). The product can be used to strengthen students' conceptual understanding on the topic of molecular shape.
\end{abstract}

Keywords: 3D printer, conceptual understanding, inorganic molecular shape

DOI: https://doi.org/10.15575/jtk.v6i2.12988

\section{Introduction}

Chemistry is a branch of science that is considered difficult and abstract because the concepts that are studied cannot be directly observed by humans. For example, the topic of atomic structure, chemical bonding, molecular shape, and many other concepts that require strong visualization, so are not easily explained verbally (Prasetyawati, 2016).

In the 2013 Curriculum, all learning activities are student-centered (Prasetyawati, 2016). Therefore, students are required to learn actively and be directly involved in the learning process. It is intended that students can find abstract chemical concepts and feel meaningfulness in the learning process (Setiawan et al., 2018).

Considering that chemistry contains several abstract and complex concepts, teachers need visualization tools in visualizing these concepts so that they are easy to understand. This is because the use of visualization tools can help embed concepts more concretely manner so that learning runs effectively and efficiently (Anas, 2014). Therefore, learning 
media have an important role in chemistry learning.

One of the chemistry topics that require the visualization tool is molecular shape the use of visualization tools on the topic of molecular shape, especially in inorganic compounds can help to visualize atoms and their bonds. Based on the interview's result with the chemistry teacher at SMA Negeri 1 Kalasan, Yogyakarta, the topic of molecular shapes is quite challenging for students because they have to learn amidst limitations such as the use of 2dimensional images and organic molymod and it is difficult to imagine the real shape of an inorganic molecule. In addition, the fact in the academic year of 2019/2020 indicates that the average Final Semester Assessment of students on the topic of molecular shape is 64.2.

Currently, there has been much development of molecular shape visualization tools to assist teachers in strengthening students' concepts. Hasibuan \& Jahro (2020) have developed a molecular shape learning kit based on rice husks. However, it still has a weakness in terms of its durability because it can naturally decompose. Therefore, molecular shape visualization tools that have good durability are needed, so that they can be used repeatedly over a long time.

In this digital era, it is possible to create tools that can help teachers and students in supporting the learning process. One of them is 3D Printer, a tool that has advantages in producing accurate and durable products (Comina et al., 2014). In developing inorganic molecular shape visualization tools, the desired design can be drawn or designed through a CAD-based application and directly printed by the 3D Printer in 3-dimensional form.

Based on the problem description, the researchers have the initiative to develop a product in the form of a 3D printer-based inorganic molecular shape model. This innovative visualization tool can complement the limitations of organic molymod in general. This teaching aid can also strengthen the students' conceptual understanding of the topic of molecular shape.

Visualization tools are conventional learning media in the form of concrete objects that are designed, made, and arranged in such a way as a tool to instill concepts to make them easier for students to accept (Anas, 2014). Good visualization tools have certain criteria and characteristics. Asmaningrum (2017) explained that good visualization tools must be durable, have attractive shapes and colors, able to present and clarify the concepts, have a size that is following the students' physical conditions, visible, not harmful to students, easy to store, and easy to use.

In chemistry learning, visualization tools have an important role in helping students understand abstract chemical concepts. This is because some concepts cannot be observed directly or exist in micro-states such as atomic, molecular structures, etc. (Martilia et al., 2017). In addition, visualization tools can be used as a means to create attractive learning conditions, thereby creating a perception in students that learning chemistry is fun and not boring (Oktiarmi, 2019).

3D Printer is a tool that capable of printing designs into 3-dimensional objects (Kelly, 2014: 5). Design making can be done using a Computer-Aided Design (CAD) based application and the results can be directly exported to the 3D printer for printing (Coward, 2015: 3-4). According to Pinger et al. (2020), this 3D printer technology has been widely used in the chemistry education world since 2012 and there has been popularity increasing trend in helping the chemistry learning process. One of the utilities of $3 \mathrm{D}$ printers in helping the chemistry learning process is loading the visualization tools through the 3D printer.

The visualization tools are used to help build the concepts for students. According to Nahdi et al. (2018), students are considered to have an understanding of the concept if they can understand the meaning or sense of a concept and can explain again based on their understanding. In addition, Anderson \& 
Krathwohl (2010) explained that the conceptual understanding indicator includes the seven cognitive processes such as the ability to interpret, classify, exemplify, summarize, infer, compare, and explain.

One of the chemistry topics that require visualization tools to make it easier to understand the concept is molecular shapes. In this topic, several approaches are used to predict the molecular shape and one of them is Electron Domain-Theory (Khery et al., 2019). In general, a molecular shape can be seen from two categories, namely the form of molecules with a central atom that only has lone electron pairs (PEI) and a central atom that has PEI and bonding electron pairs (PEB). The shape of the molecule formed from the central atom which only has $\mathrm{PEl}$, which are linear, trigonal planar, tetrahedral, trigonal bipyramidal, and octahedral. Meanwhile, the shape of the molecule formed from a molecule with a central atom having PEI and PEB, which are the letter $\mathrm{V}$, trigonal pyramidal, seesaw, bent $T$, square base pyramid, and planar quadrilateral (Effendy, 2017).

Based on the previous study, this research aims to create the product in the form of a 3D printer-based inorganic molecular shape model following the ADDIE development model; analyze validity, practicality, and effectiveness of the product; and analyze the students' conceptual understanding while using the product.

\section{Research Method}

This research used Research and Development (R\&D) method. This method is used to find, develop, and validate products (Sugiyono, 2009). By referring to this method, the final product in the form of the 3D Printer-based inorganic molecule model is expected to fulfill the valid, practical, and effective criteria and also is feasible to be applied in chemistry learning.

This method adopts the ADDIE development model which consists of five stages: Analysis, Design, Development, Implementation, and Evaluation (Lee \& Owen, 2004). The analysis stage includes material, needs, and environmental analysis. The design stage includes the creation of atomic designs, bonds, kits, and kit covers. The development stage carried out the product printing, product refinement, product coloring, product packaging, and validation. The implementation stage includes product legibility testing and field trials. The evaluation stage is carried out to assess the final product can fulfill the criteria of validity, practicality, and effectiveness.

The research was carried out at SMA Negeri 1 Kalasan. The product readability test involved three students and was followed by field trial with 35 students in one classroom.

The research instruments used in this study were product and instrument validation sheets, product readability questionnaire, pretest and posttest questions, questions during the field trial, students' conceptual understanding observation sheet, and students' response questionnaire to a product. Validation was carried out by four validators consisting of two chemistry education lecturers and two high school chemistry teachers. The pretest-posttest instrument and students' response questionnaire were carried out online using google form. Meanwhile, the validation, questions during the trial, and observation sheets were offline carried out. The analysis of the validity results was carried out using the following equation (1) and (2).

$$
\mathrm{Va}_{\mathrm{n}}=\frac{\mathrm{TSe}}{\mathrm{TSh}} \times 100 \%
$$

The final validation scores of the experts were averaged. The final validation equation used is as follows.

$$
\mathrm{V}=\frac{\mathrm{Va}_{1}+\mathrm{Va}_{2}+\mathrm{Va}_{3}+\mathrm{Va}_{4}}{\mathrm{n}}
$$

Information:

$V a_{n}=$ Validity on the $\mathrm{n}$ validator

$V a_{1}=$ Validity of expert 1

$V a_{2}=$ Validity of expert 2

$V a_{3}=$ Validity of expert 3

$V a_{4}=$ Validity of expert 4

$\mathrm{V}=$ Validity coefficient

$\mathrm{n}=$ number of validator

TSh= maximum total score

$\mathrm{TSe}=$ empirical score (result from validator) 
Table 1. Criteria of Validity Coefficient

\begin{tabular}{cc}
\hline Value & Criteria \\
\hline $85,01 \%-100 \%$ & Very High \\
$70,01 \%-85 \%$ & High \\
$50,01 \%-70 \%$ & Low \\
$01,00 \%-50 \%$ & Very Low \\
\hline & (Akbar, 2013)
\end{tabular}

The analysis of the achievement of the conceptual understanding indicator was carried out descriptively and was carried out through the following equation (3) (Alghiri et al., 2018).

$\%(P)=\frac{\text { Number of indicators achieved }}{\text { number of indicators }} \times 100 \%$

Table 2. Criteria of Student's Conceptual Understanding

\begin{tabular}{cc}
\hline Percentage (\%) & Category \\
\hline $81 \leq \mathrm{P} \leq 100$ & Very High \\
$61 \leq \mathrm{P}<80$ & High \\
$41 \leq \mathrm{P}<60$ & Moderate \\
$21 \leq \mathrm{P}<40$ & Low \\
$0 \leq \mathrm{P}<20$ & Very Low \\
\hline & (Alghiri et al., 2018)
\end{tabular}

The effectiveness of the product can be analyzed through equations ( 3 ) and converted into Table 3.

Table 3. Criteria of Product's Effectiveness

\begin{tabular}{cc}
\hline Interval (\%) & Criteria \\
\hline $81-100$ & Very High \\
$61-80$ & High \\
$41-60$ & Moderate \\
$21-40$ & Low \\
$0-20$ & Very Low \\
\hline
\end{tabular}

(Riduwan, 2009)

The practicality of the product is analyzed based on the results of the student response questionnaire to the product through equation 4 (Widoyoko, 2012).

$\%(R)=\frac{\text { The average of students' response scores }}{\text { Maximum number of scores }} \times 100 \%$

Table 4. Criteria of Product's Practicality

\begin{tabular}{cc}
\hline Interval (\%) & Criteria \\
\hline $81-100$ & Very Practical \\
$61-80$ & Practical \\
$41-60$ & Practical Enough \\
$21-40$ & Impractical \\
$0-20$ & Very Impractical \\
\hline
\end{tabular}

(Riduwan, 2009)

\section{Result and Discussion}

\subsection{Development of Inorganic Molecular Shape Model Using ADDIE Model Analysis Stage.}

Based on the study result on the chemistry topic following with chemistry syllabus of class $X$ for the academic year of 2020/2021 on the topic of molecular shape (basic competencies 3.7 and 4.7), it is known that there are 14 molecular shapes studied according to the VSEPR theory. The molecular shape studied are linear $\left(A X_{2}\right)$, trigonal planar $\left(A X_{3}\right), V$ shape $\left(A X_{2} E\right)$, tetrahedral $\left(A X_{4}\right)$, trigonal pyramidal $\left(A X_{3} E_{1}\right)$, $V$ shape $\left(A X_{2} E_{2}\right)$, linear $\left(A X E_{3}\right)$, trigonal bipyramid $\left(A X_{5}\right)$, tetrahedral distorted $\left(A X_{4} E\right), T$ shape $\left(A X_{3} E_{2}\right)$, linear $\left(A X_{2} E_{3}\right)$, octahedral $\left(A X_{6}\right)$, square-based pyramid $\left(\mathrm{AX}_{5} \mathrm{E}\right)$, and planar quadrilateral $\left(A X_{4} E_{2}\right)$ (Effendy, 2017).

Furthermore, based on the interview analysis with the chemistry teacher at grade 10, molecular shapes require media such as molecular shape visualization tools that can visualize all the shapes of the molecules being studied. It's needed because students still have difficulty imagining the real molecular shape and difficulty in memorizing the names of each molecular shape. Therefore, the visualization tools that can visualize all the shapes of the molecule being studied are needed.

Based on the environmental analysis, it is known that one of the senior high schools in Yogyakarta still does not have the visualization tools to visualize all the molecular shapes. In addition, visualization tools are difficult to be found in the offline and online market.

\subsection{Design Stage}

At this stage, the design of the atom, bond, kit, and kit cover is made. Atomic and bond designs are made through the AutoCAD application because this application is easy to use to create two-dimensional and threedimensional designs (Sastra, 2019). The atomic designs made are $\mathrm{H}, \mathrm{Be}, \mathrm{B}, \mathrm{N}, \mathrm{O}, \mathrm{F}, \mathrm{Si}, \mathrm{P}, \mathrm{S}, \mathrm{Cl}$, $\mathrm{Br}$, and $\mathrm{Xe}$. The kit box design includes the base case, cover box, bulkhead, and bulkhead cover. The design for the kit cover was made using CorelDRAW 2020 to provide an identity 
for the product. The design of the atom and stick can be seen in Figure 1.

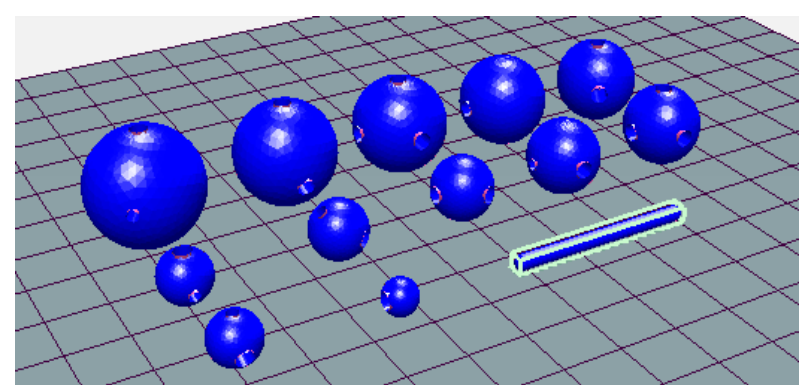

Figure 1. The Design of the Atom and Stick

\subsection{Development Stage}

At this stage, the atomic design and bonds are printed using a 3D printer to produce a product in three-dimensional (real) form. After that, the product is refined and gives the color according to the following Table 5 (Helmenstine, 2020).

Table 5. Atomic Colour List

\begin{tabular}{cc|c}
\hline Atom & $\begin{array}{c}\text { Colour Code } \\
\text { (RGB) }\end{array}$ & Colour \\
\hline $\mathrm{H}$ & {$[255,255,255]$} & \\
$\mathrm{Be}$ & {$[194,255,0]$} & \\
$\mathrm{B}$ & {$[255,181,181]$} & \\
$\mathrm{N}$ & {$[48,80,248]$} & \\
$\mathrm{O}$ & {$[255,13,13]$} & \\
$\mathrm{F}$ & {$[144,224,80]$} & \\
$\mathrm{Si}$ & {$[240,200,160]$} & \\
$\mathrm{P}$ & {$[255,128,0]$} & \\
$\mathrm{S}$ & {$[255,255,48]$} & \\
$\mathrm{Cl}$ & {$[31,240,31]$} & \\
$\mathrm{Br}$ & {$[166,41,41]$} & \\
$\mathrm{Xe}$ & {$[66,158,176]$} & \\
\hline
\end{tabular}

This product staining is done to give each atom an identity so that it is easier to be recognized. The product that has been given the color is then packaged using a kit made of plywood $(4 \mathrm{~mm})$ and adjusted to its bulkhead part. The compounds that can be made using this product are $\mathrm{BeCl}_{2}, \mathrm{BF}_{3}, \mathrm{SO}_{2}, \mathrm{SiCl}_{4}, \mathrm{NH}_{3}$, $\mathrm{H}_{2} \mathrm{O}, \mathrm{HF}, \mathrm{PCl}_{5}, \mathrm{SF}_{4}, \mathrm{ClF}_{3}, \mathrm{XeF}_{2}, \mathrm{SF} 6, \mathrm{BrF}_{5}$, and $\mathrm{XeF}_{4}$. The product can be seen in Figure 2. Examples of finished molecular shapes can be seen in Figure 3.

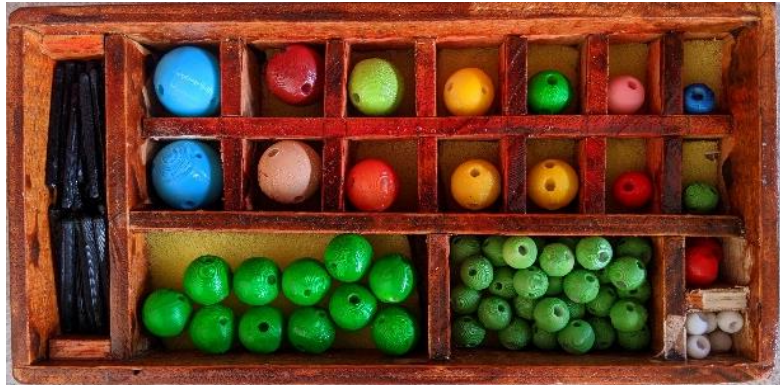

Figure 2. Product

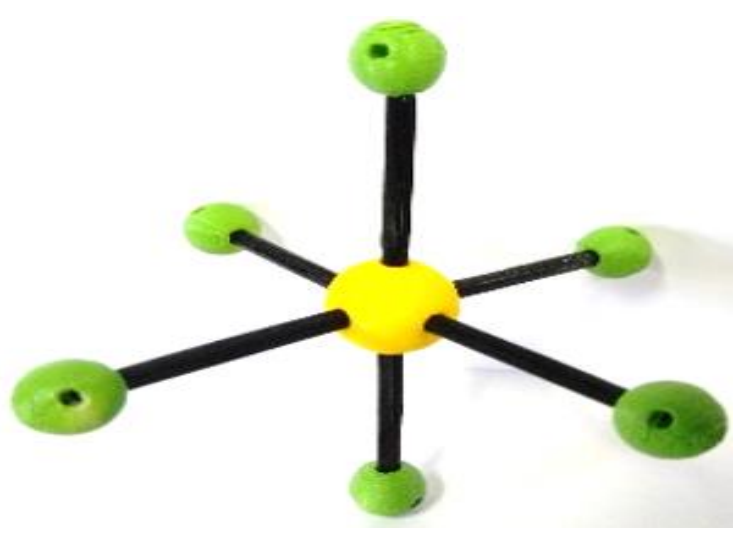

A

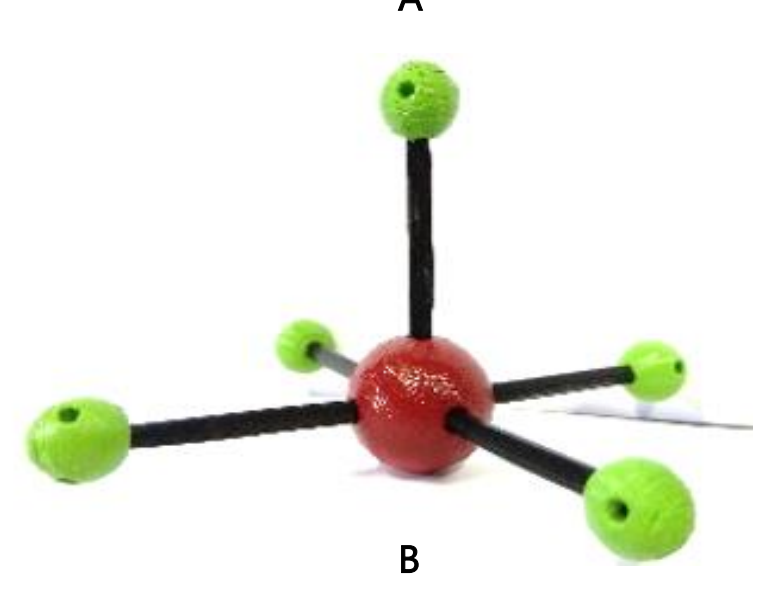

Figure 3. Molecular Shapes of $\mathrm{SF}_{6}(\mathrm{~A})$ and $\mathrm{BrF}_{5}(\mathrm{~B})$

\subsection{Implementation Stage}

This stage is carried out in two stages: product readability testing and field trial. This stage is important to do to find out the usefulness of the products that have been produced (Rayanto et al., 2020). The product readability test was carried out with three students with different cognitive levels, so it is hoped that this product can be used for all students regardless of their cognitive ability. The results of the analysis show that this product has a 
very good readability level criterion (Widoyoko, 2012).

Field trials were carried out in several stages: pretest, offline trial, and posttest. Based on the results of this Rasch model using Winstep, it was found that at the pretest stage, the consistency of students' answers was 0.55 (weak), the quality of the items was 0.91 (very good), the interaction of the students' answers consistency with the questions was 0.31 (bad). (Sumintoni et al., 2015). The questions during the trial were done with the help of the product by offline at school. This offline trial was conducted to determine the usefulness of the product in understanding molecular shape. The results of the analysis using Rasch at the pretest stage showed that the consistency of students' answers was 0.71 (quite good), the quality of the items was 0.93 (very good), and the interaction between the consistency of students' answers was 0.68 (quite good) (Suminto et al., 2015). The following is a comparison of the average results of the pretest and posttest scores.

\section{Average Results of the Pretest and Posttest Scores}

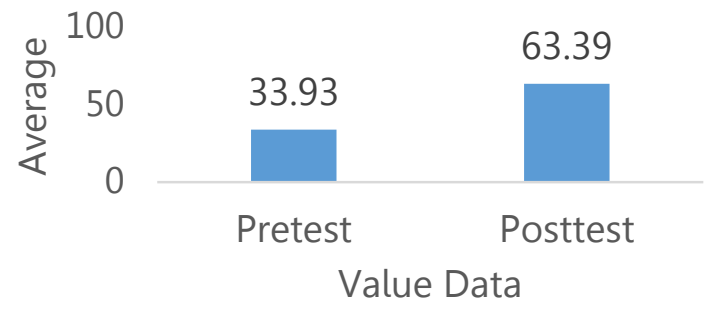

Figure 4. Average Results of the Pretest and Posttest Scores

\subsection{Evaluation Stage}

In general, products in the form of inorganic molecular shape models based on 3D printers are good and can be used in chemistry studies on the topic of molecular shape. However, there are several suggestions given by the validator, so that this product can be even better. The suggestion given relates to the size of the bond (stick) which is slightly smaller than the atomic hole, so that when the bond (stick) is paired it becomes loose and easily detaches. The next input is to smooth the part of the bulkhead cover that is still sharp so as not to injure the user. Therefore, it is necessary to increase the number of bonds (sticks) in each kit to anticipate if there is a bond (stick) that has a size that does not match the atomic holes. In addition, the corners of the bulkhead cover are smoothed so as not to injure the user.

During the experiment, there were several atoms accidentally dropped in places that were difficult to reach, such as under concrete racks and sinks. Atoms that are prone to loss are atoms $\mathrm{F}$ and $\mathrm{Cl}$ (companion atoms) because the two atoms have the highest number of atoms and one bulkhead contains 28 for $\mathrm{F}$ atoms and 11 for $\mathrm{Cl}$ atoms. In contrast to the central atom which only consists of one atom from each bulkhead, other companion atoms whose number does not exceed five atoms in each block when something is missing will be more easily detected. Therefore, the addition of companion atoms, especially $\mathrm{F}$ and $\mathrm{Cl}$ atoms, is done to anticipate when one day the two atoms are lost and unknown by the user.

\subsection{Validity, Practicality, and Effectiveness of Product}

Plomp \& Nieveen (2007) stated that the product developed must have valid, practical, and effective criteria. The resulting product validity was obtained from the validation results of the four validators. The product practicality was obtained from the results of the student response questionnaire after using the product, and the effectiveness of the product was obtained based on the results of the observation during the trial.

Plomp \& Nieveen (2007) also explained that a product is said to be valid if it is following the components that underlie the product development. This product is made based on the criteria of a good visualization tool including product appearance, practicality, durability, safety, ease of use, suitability with the learning topics (Asmaningrum, 2017). The result of product validation is shown in Table 6. 
Table 6. Result of Product Validation

\begin{tabular}{|c|c|c|c|}
\hline No & Aspect & $\begin{array}{c}\text { Average } \\
\text { Scores } \\
(\%)\end{array}$ & Criteria \\
\hline 1 & Display & 91,67 & Very High \\
\hline 2 & Practicality & 100 & Very High \\
\hline 3 & Durability & 98,44 & Very High \\
\hline 4 & Safety & 96,88 & Very High \\
\hline 5 & $\begin{array}{l}\text { Easiness using } \\
\text { product }\end{array}$ & 97,92 & Very High \\
\hline 6 & $\begin{array}{l}\text { Product } \\
\text { suitability with } \\
\text { molecular } \\
\text { shape }\end{array}$ & 97,92 & Very High \\
\hline \multicolumn{2}{|c|}{ Average } & 97,14 & Very High \\
\hline
\end{tabular}

The results of the assessment obtained from validators show that the products produced have an average percentage of $97.14 \%$; so that the validity of this product is very high (Akbar, 2013). The practicality of the product is based on the results of the students' response questionnaire to the product and the average percentage is $95.17 \%$, so this product is classified as very practical. The effectiveness of the product is seen based on the results of observations and obtained an average percentage of $94.69 \%$; so this product is classified as very effective (Riduwan, 2009).

\subsection{Using Product for Strengthening Students' Conceptual Understanding}

Product development in the form of a 3D printer-based inorganic molecular shape model aims to visualize the 14 molecular shapes so that students can more easily understand the concept. Therefore, at the implementation stage, all parts are directed at seven indicators of conceptual understanding, namely interpreting (B1), providing examples (B2), classifying (B3), summarizing (B4), drawing inferences (B5), comparing (B6), and explaining (B7) (Anderson et al., 2010). This is done to determine the effect of using the product on the students' conceptual understanding ability. The results of the conceptual understanding analysis during the trial can be seen in Figure 5 .

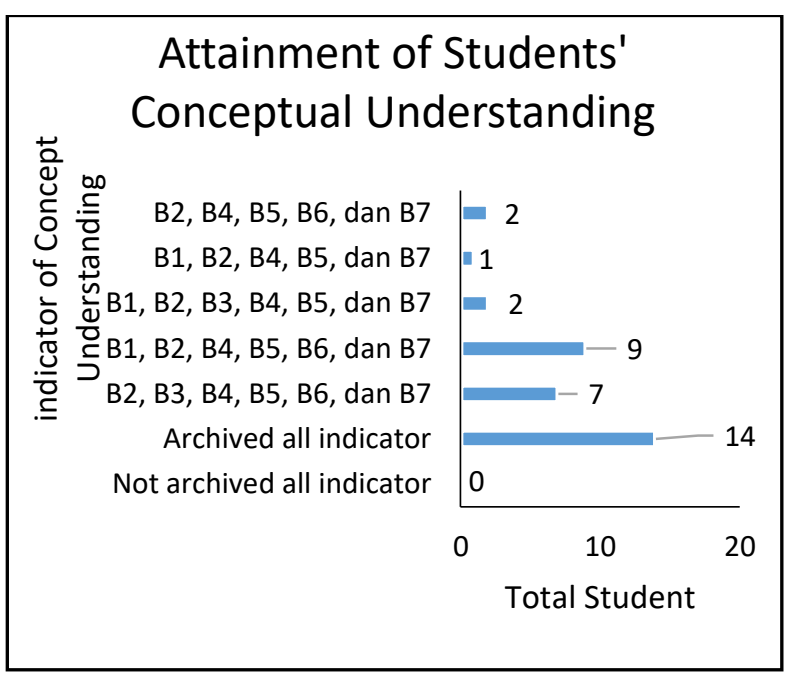

Figure 5. Achievement of Students' Conceptual Understanding during Trial

During the trial, students are expected to be able to determine the electron configuration, Lewis structure, molecular notation, molecular shape, and bond angles with the help of the product. In the early stages of work, it was seen that students were still having difficulty in determining electron configuration, determining valence electrons, and Lewis structures. However, the researchers explained the function of the product in the form of a 3D printer-based molecular shape model. This 3D printer can show the number of valence electrons which can be seen from the holes of the atoms used where one large hole (to insert bonds) has one electron and one small hole indicates the presence of lone pair electron (consists of two electrons). In addition, after the shape of the molecule is assembled, there are lone electron pairs and bonding electron pairs of each atom used, so that it can be used to help students create their Lewis structures. However, this product cannot help in making electron configurations.

During using a product, there was one student cannot make electron configurations, three students were not able to make Lewis structures, one student was not able to determine valence electrons, and four students were not able to make electron configurations and Lewis structures. In determining valence electrons and making Lewis structures, students who have succeeded in determining valence electrons and Lewis structures with the help of products 
are allowed to teach their friends how to use the product to help in finding the valence electrons and the Lewis structures. This is intended, so students can learn directly with peers and students who have mastered the material to deepen it even more. According to Nahdi et al. (2018) explained that by reexplaining the concept using their language and understanding to others it can strengthen the understanding of the concept it has.

In addition, another obstacle was found that there was one student who was confused in determining the name of the molecular shape. Therefore, the researcher asked students to imagine the shape of the molecule they had made using the product and began to guess its name according to its shape. For example, the compound $\mathrm{SF}_{4}$ when placed on the table will look like a seesaw. However, there is a problem with the shape of the $\mathrm{BF}_{3}$ and $\mathrm{ClF}_{3}$ compounds because they generally have a triangular shape. Therefore, students are given directions to look for objects that are similar to the shape of $\mathrm{ClF}_{3}$ but other than the shape of a triangle. In the end, the students realized that the $\mathrm{ClF}_{3}$ compound was almost the same as $\mathrm{T}$ shape. The shape of the $\mathrm{BF}_{3}$ molecule can be seen in Figure 6 and $\mathrm{ClF}_{3}$ in Figure 7.

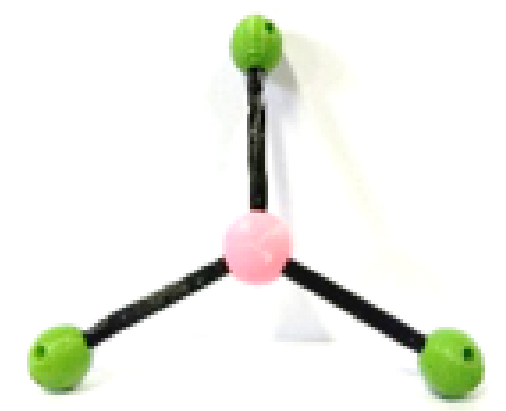

Figure 6. Molecular Shape of $\mathrm{BF}_{3}$

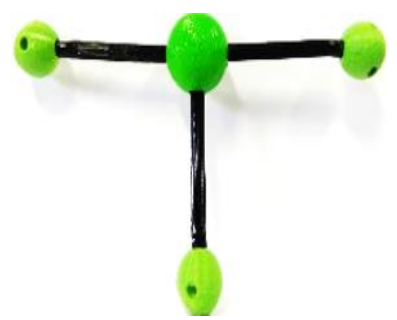

Figure 7. Molecular Shape of $\mathrm{ClF}_{3}$
During the trial, this product can help students determine the bond angle qualitatively. Therefore, for some compounds with angles that are difficult to see the difference directly, such as $\mathrm{NH}_{3}\left(107^{\circ}\right), \mathrm{H}_{2} \mathrm{O}\left(104.5^{\circ}\right), \mathrm{SO}_{2}\left(119^{\circ}\right)$, and $\mathrm{SiCl}_{4}\left(109.5^{\circ}\right)$, students are asked to be provided with a list of the table of angles and compounds randomly and asked to compare bond angles using the obtained products. Although it is quite difficult to distinguish the angles between molecules due to the small differences in angles, in the end, students can determine the bond angles of the selected molecules after comparing the four compounds. The shape of the $\mathrm{NH}_{3}$ molecule can be seen in Figure $8, \mathrm{H}_{2} \mathrm{O}$ in Figure $9, \mathrm{SO}_{2}$ in Figure 10, and $\mathrm{SiCl}_{4}$ in Figure 11.

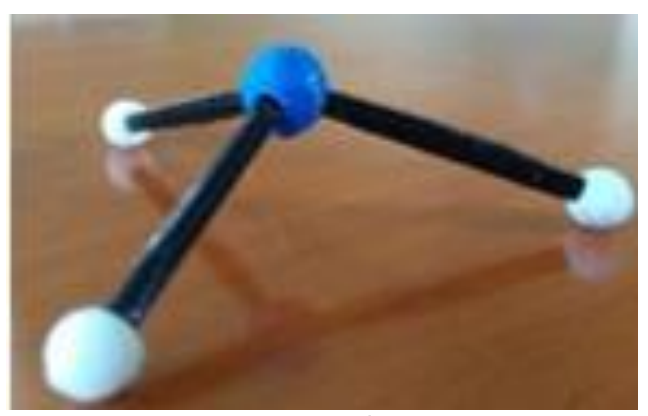

Figure 8. Molecular Shape of $\mathrm{NH}_{3}$

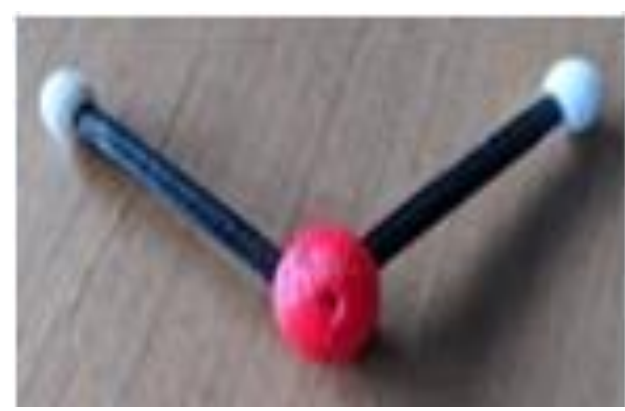

Figure 9. Molecular Shape of $\mathrm{H}_{2} \mathrm{O}$

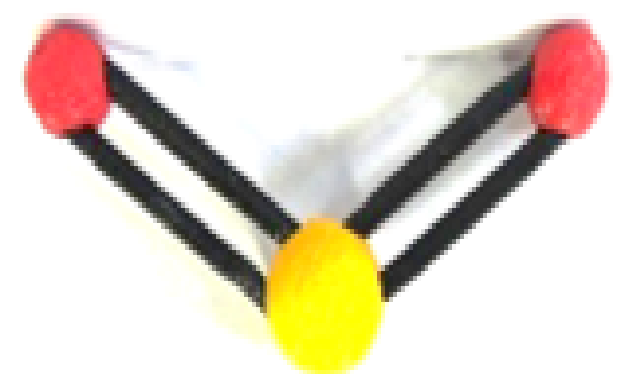

Figure 10. Molecular Shape of $\mathrm{SO}_{2}$ 


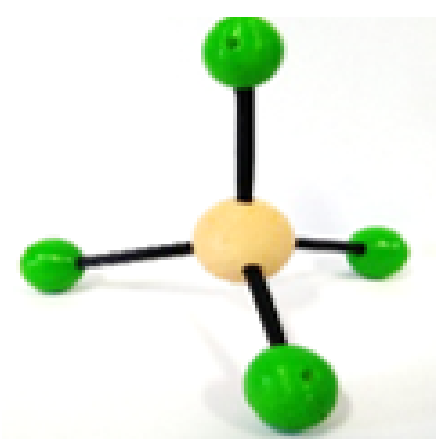

Figure 11. Molecular Shape of $\mathrm{SiCl}_{4}$

Two observers observed the achievement of the conceptual understanding indicators. These results are following the results of observations where the abilities of students are in the very high and high categories. The results of the observations can be seen in Figure 12.

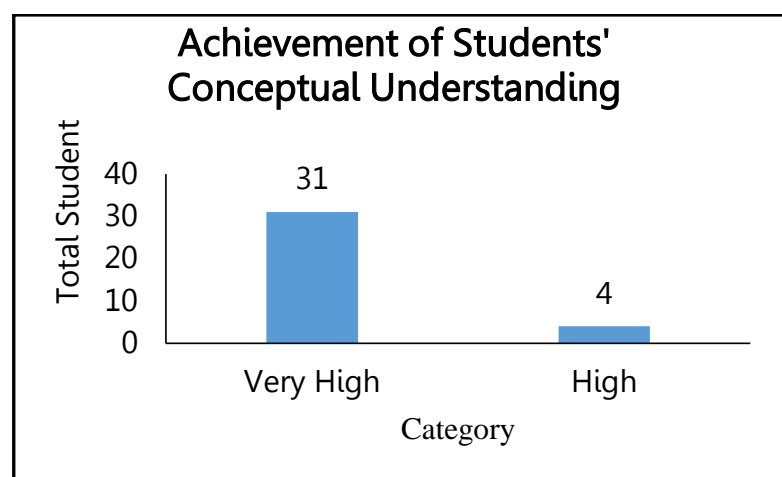

Figure 12. Achievement of Students' Conceptual Understanding through Observation

Based on the result of observation during the trial, this product can strengthen students' understanding of concepts on the topic of molecular shapes. The average percentage of conceptual understanding achievement during the trial was $90.61 \%$ and the observation result was $94.69 \%$, which is included in the very high category (Alghiri et al., 2018).

In addition to the data during the trial, there were four pretest and posttest questions based on seven indicators of conceptual understanding. In question number 1, students must be able to explain and summarize the three concepts in determining the shape of a molecule. So, there are two indicators of conceptual understanding that must be achieved, namely explaining (B6) and summarizing (B7).
In question number 2, the students can compare the number of lone electron pairs and bonding electron pairs and their molecular shape, explain the bond angles of $\mathrm{NH}_{3}$ and $\mathrm{H}_{2} \mathrm{O}$ compounds and be able to draw inferences regarding the effect of lone electron pairs and electron pairs on the bond angle. So, there are three indicators of concept understanding, namely comparing (B1), attracting inference (B2), and explaining (B6). Molecule shape of $\mathrm{NH}_{3}$ can be seen in Figure 8 and $\mathrm{H}_{2} \mathrm{O}$ in Figure 9.

In question number 3, students are expected to be able to interpret $\mathrm{PCl}_{5}$ and $\mathrm{SF}_{6}$ compounds to find out the number of lobe pair electron and electron pair starting from making electron configurations to making Lewis structures. After that, students are expected to be able to make inferences regarding the molecular notation of $\mathrm{PCl}_{5}$ and $\mathrm{SF}_{6}$ compounds. So, two indicators of understanding the concept that must be achieved are interpreting (B3) and making inferences (B2). The molecular shape from this product can show the molecule shape of $\mathrm{PCl}_{5}$ in Figure 13 dan $\mathrm{SF}_{6}$ in Figure 14.

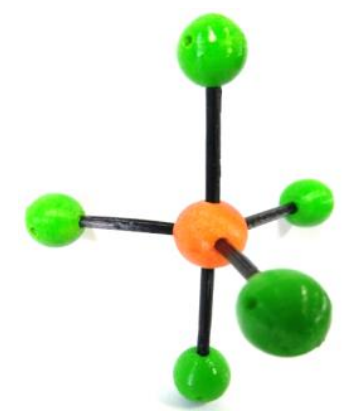

Figure 13. Molecular Shape of $\mathrm{PCl}_{5}$

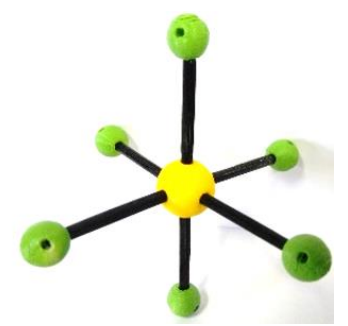

Figure 14. Molecular Shape of $\mathrm{SF}_{6}$

In question number 4, students can classify various compounds according to the molecular notation $\mathrm{AX}_{4} \mathrm{E}$ and $\mathrm{AX}_{4} \mathrm{E}_{2}$, then provide examples of compounds that best 
match the notation. After that, students are expected to be able to interpret the molecular shape and bond angles of the compounds they have modeled. So, three indicators of conceptual understanding that must be achieved are interpreting (B3), providing exemplifying (B4), and classifying (B5). If using this product, the most suitable compounds are $\mathrm{SF}_{4}$ and $\mathrm{XeF}_{4}$. The molecular shape of $\mathrm{SF}_{4}$ can be seen in Figure 15 dan $\mathrm{XeF}_{4}$ in Figure 16.

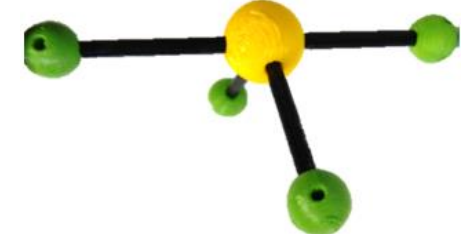

Figure 15. Molecular Shape of $\mathrm{SF}_{4}$

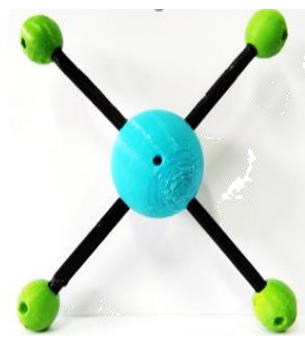

Figure 16. Molecular Shape of $\mathrm{XeF}_{4}$

In each of the pretest and posttest questions, an analysis of the achievement of the conceptual understanding indicators was carried out. Based on the result, this indicates that this product has a positive impact on the students' conceptual understanding. In addition, this data is strengthened from the average percentage of conceptual understanding achievement at the pretest of $24 \%$ to $70 \%$ based on the posttest results (Alghiri et al., 2018).

\section{Conclusion}

The development of a 3D printer-based inorganic molecular shape is following the ADDIE development model because it is complete, simple, and systematic. This development model details the stages that must be carried out so that a good final product is obtained. The product validation has an average value of the validator of $91.67 \%$; so it has very high validity. The average percentage of the practicality of the product is $95.17 \%$ that comes from an average of the questionnaire's response; so this product is included in the very practical criteria. The average percentage of product effectiveness is $94.69 \%$, so this product is included in the very effective criteria. The utility of the product has a positive impact, which can be seen from the results of trials and observations that the product can strengthen students' conceptual understanding on the topic of molecular shapes by the average percentage of concept understanding's achievement during the trial was $90.61 \%$ and the observation result was $94.69 \%$, which is included in the very high category as well as an increase in the achievement of conceptual understanding indicators from 24\% (pretest) to $70 \%$ (posttest).

\section{References}

Akbar, S. (2013). Instrumen perangkat
pembelajaran. Bandung:
Rosdakarya.

Alighirl, D., Drastisianti, A., \& Susilaningsih, E. (2018). Pemahaman konsep siswa materi larutan penyangga dalam pembelajaran multiple representasi. Jurnal Inovasi Pendidikan Kimia, 12(2), 2092-2200.

https://doi.org/10.15294/jipk.v12i2.15 735

Anas, M. (2014). Alat peraga dan media pembelajaran. Jakarta: Pustaka Education.

Anderson, L., \& Krathwohl, D. (2010). Kerangka landasan untuk pembelajaran, pengajaran, dan assesmen. Yogyakarta: Pustaka Belajar.

Asmaningrum, H. P. (2017). Efektivitas penggunaan alat peraga terhadap hasil belajar kimia dan fisika pada siswa kelas IX SMP Satu Atap Wasur Merauke. Jurnal Inovasi Pendidikan SAins, 8(2), 69-77. http://dx.doi.org/10.20527/quantum.v $8 \mathrm{i} 2.4015$

Asmuni. (2020). Problematika pembelajaran daring di masa pandemi Covid-19 dan

Jurnal Tadris Kimiya 6, 2 (December 2021): 144-155 
solusi pemecahannya. Jurnal Paedagogy: Jurnal Penelitian dan Pengembangan Pendidikan, 7(4), 281288. https://doi.org/10.33394/jp.v7i4.2941

Comina, G., Suska, A., \& Filippini, D. (2014). Low-cost lab-on-a-chip prototyping with a consumer-grade 3D printer. $L a b$ on a Chip, 14(16), 1-5. Retrieved from https://pubs.rsc.org/en/content/article html/2014/lc/c4lc00394b

Coward, C. (2015). 3D Printing. New York: Penguin Group (USA) Inc.

Effendy. (2017). Mulekul, struktur, dan sifatsifatnya. Malang: Indonesia Academic Publishing.

Hasibuan, A. Y., \& Jahro, I. S. (2020). Pengembangan KIT pembelajaran dari limbah sekam padi pada materi bentuk molekul kelas X SMA. Jurnal Inovasi Pembelajaran Kimia, 2(1), 6-10. https://doi.org/10.24114/jipk.v2i1.166 33

Helmenstine, T. 2020. Molecule atom colorscpk colors. Scientific instrument, 24 (9). Retrieved from https://sciencenotes.org/moleculeatom-colors-cpk-colors/

Kelly, J. F. (2014). 3D Printing: build your own $3 d$ printer and print your own $3 D$ objects. USA: Pearson Education Inc.

Khery, Y., Nufida, A., \& Suryanti. (2019). Kimia Umum. Yogyakarta: CV Budi Utama.

Lee, W.W dan Owens, D.L. (2004). Multimediabased instructional design (second edition). San Fransisco: Pfeiffer.

Nahdi, D. S., Yonanda, D. A., \& Agustin, N. F. (2018). Upaya meningkatkan pemahaman konsep siswa melalui penerapan metode demonstrasi pada mata pelajaran IPA. Jurnal Cakrawala Pendas, 4(2), 9-16. Retrieved from https://core.ac.uk/download/pdf/2288 82831.pdf
Oktiarmi, P. (2019). Pengembangan alat peraga kimia sederhana (algatomiokul) pada materi atom, ion, dan molekul untuk meningkatkan aktivitas belajar siswa. Jurnal Guru Dikmen \& Diksus, 2(2), 41-50. Retrieved from https://jgdd.kemdikbud.go.id/index.p hp/jgdd/article/download/36/16

Pinger, C. W., Geiger, M. K., \& Spence, D. M. (2020). Applications of 3D-printing for improving chemistry education. Journal of Chemistry Education, 97(1), 112-117. Retrieved from https://doi.org/10.1021/acs.jchemed.9 b00588

Plomp, T., \& Nieveen, N. (2007). An introduction to educational design research. 89 in proceedings of the seminar conducted at the East China Normal University, Shanghai: PR China.

Prasetyawati, P. (2016). Analisis pembelajaran student centered learning dalam pendekatan saintifik pada mata pelajaran sejarah di SMA Negeri sekota Palu. Jurnal Katalogis, 4(10), 130-137. Retrieved from http://jurnal.untad.ac.id/jurnal/index.p $\mathrm{hp} /$ Katalogis/article/view/7010

Rayanto, Y. H., \& Sugianti. (2020). Penelitian pengembangan model ADDIE dan R2D2: teori dan praktek. Pasuruan: Lembaga Academic \& Research Institute.

Riduwan. (2009). Belajar mudah penelitian untuk guru-karyawan dan peneliti pemula. Bandung: Alfabeta.

Setiawan, I., Indriyanti, N. Y., \& Mulyani, S. (2018). Profil pembelajaran kimia berbasis kurikulum 2013 di kota Gorontalo dan Kota Surakarta Kelas X tahun ajaran 2016/2017. Jurnal Inovasi Pendidikan Kimia, 12(1), 2039-2054. Retrieved from https://doi.org/10.15294/jipk.v12i1.13 296 
Development of Inorganic Molecular Shape Model Using 3D Printer to Strengthen Student's Conceptual Understanding

Sugiono. 2009. Metodologi penelitian kualitatif dan R\&D. Bandung. Alfabeta

Sumintono, B., \& Widhiarso, W. (2015). Aplikasi pemodelan rasch pada assessment pendidikan. Bandung: Alfabeta.

Widoyoko, E. P. (2012). Teknik penyusunan instrumen penelitian. Yogyakarta: Pustaka Pelajar.
Zuchdi, D. (2011). Pendidikan karakter dalam perspektif teori dan praktik . Yogyakarta: UNY Press.

Zulvianda, H., Hanum, L., \& Nazar, M. (2013). Pengembangan e-module kimia SMA pada materi larutan elektrolit dan non elektrolit. Jurnal Ilmiah Mahasiswa Pendidikan Kimia (JIMPK), 1(3), 9-16. Retrieved from http://www.jim.unsyiah.ac.id/pendidikan -kimia/article/view/1295 